\title{
Training Needs in Light of the Digital Revolution to Develop the Skills of Social Studies Female Teachers
}

\author{
Hosah Almelweth ${ }^{1 *}$, Amel Alkahtani ${ }^{2}$ \\ ${ }^{1}$ Associate Professor of Curricula and Teaching Methods of Social Studies, College of Education, King Khalid University, KSA \\ ${ }^{2}$ Assist. Professor of Educational Technology, College of Education, Princess Nourah bint Abdulrahman University, KSA \\ Received 30 January 2018 - Revised 19 April 2018 - Accepted 30 May 2018
}

\begin{abstract}
The current study aimed to identify the most important training needs in the light of the digital revolution to develop the skills of social studies female teachers. It was applied to a randomly selected sample of social studies female teachers in Asir who responded to the electronic questionnaire. It concluded that the level of the training needs in all domains (i.e. teaching in the electronic environments, technology and the educational activities, skills of the digital teacher, using learning materials and resources, skills of the action research, and evaluation) was high. In addition, it provided a proposal according to the training needs of the female teachers. Finally, it recommended holding courses and training programs by the end of each academic year according to the training needs of the female teachers in the light of the variables of the age.
\end{abstract}

Keywords: training needs, digital revolution, social sciences female teachers

\section{INTRODUCTION}

School is one of the most important institutions of socialization. With the global developments in the educational institution, it was necessary to keep pace with them, improve the performance of teachers, and improve all the inputs of the educational process. In addition, teachers' reliance on modern means of communication as well as some devices and technologies is an urgent need to improve their teaching performance. Therefore, it is necessary to respond to the changes that they experience, especially those changes that keep pace with the digital revolution, which remains one of the biggest changes in the world. It is an accelerated revolution with its characteristics associated with information which is the key pillar in life. Hence, it is the beginning of the inevitable changes of life (Redne, 2015).

It extended to cover the educational institutions and affected schools. As a result, smart schools and e-learning, which has begun to take the lead in education systems, have emerged. That is, there is a focus on self-learning (Wahba, 2011).

Accordingly, the school must be transformed into a technical environment that aims to accomplish networking between classrooms and facilities, mastering computer technology, and motivating teachers to develop their skills in dealing with technology and information resources. This requires a qualified and trained teacher (Abu Elsamh \& Rahal, 2012). Hence, the programs and activities that develop the skills of teachers with their different professional levels and scientific disciplines, increasing the motivation of beneficiaries to upgrade their skills and develop their professional performance are important (Mohammad, 2007).

Care shall be given to teachers in line with the nature of challenges that the Saudi community faces in the future to become a force that compensates for the shortcomings of the past. In other words, it shall be equipped with the capacity and capabilities that enable it to assume the responsibilities to be accomplished to face the contemporary global changes.

(C) 2018 by the authors; licensee Modestum Ltd., UK. This article is an open access article distributed under the terms and conditions of the Creative Commons Attribution License (http://creativecommons.org/licenses/by/4.0/). $\square$ halmlwth@kku.edu.sa (*Correspondence) $\square$ asalqhtani@pnu.edu.sa 


\section{Contribution of this paper to the literature}

- Identifying the most important training needs in the light of the digital revolution.

- Identifying the training needs of social studies female teachers regarding teaching in electronic environments, technology and educational activities, skills of digital teacher, using learning materials and resources, skills of action research, and evaluation.

- Providing a proposal to develop the skills of social studies female teachers in the light of the digital revolution.

It is necessary to develop and train the teacher to develop his knowledge and skills that enable him to assimilate modern and constantly evolving technology. Accordingly, the present study attempts to identify the skills and methods of developing the teacher in the light of the digital revolution.

\section{STATEMENT OF THE PROBLEM}

With the introduction of modern technologies, the development of the school's objectives, and the growing demands on them, the need for training, development and continuous improvement increased. These institutions are motivated to take steps towards professional and educational development. Furthermore, training remains as the best way to accomplish the desired change. In addition, having such change requires identifying the teacher's training needs and developing an appropriate proposal of ongoing training programs. Therefore, the problem of the current study has been identified in asking the following major question: What are the training needs in the light of the digital revolution to develop the skills of social studies female teachers?

It is further subdivided into the following minor ones:

1- What are the training needs in the light of the digital revolution of social studies female teachers regarding teaching in the electronic environments (planning- strategies- interaction)?

2- What are the training needs in the light of the digital revolution of social studies female teachers regarding education technology and educational activities (education technology-educational activities)?

3- What are the training needs in the light of the digital revolution of social studies female teachers regarding the digital teacher?

4- What are the training needs in the light of the digital revolution of social studies female teachers regarding the skills of action research?

5- What are the training needs in the light of the digital revolution of social studies female teachers regarding learning materials and resources?

6- What are the training needs in the light of the digital revolution of social studies female teachers regarding evaluation?

\section{OBJECTIVES}

The study seeks to:

1- Identify the training needs in the light of the digital revolution to develop the skills of social studies female teachers in teaching planning, teaching strategies, interaction, educational activities and education technology, evaluation, skills of the digital teacher, using learning materials and resources, and skills of the action research.

2- Provide a proposal to develop the skills of social studies female teachers considering the digital revolution.

\section{SIGNIFICANCE}

- The study provides a proposal on the most important needs for social studies female teachers. This may benefit decision makers and those in charge of the educational processes.

- The results of the study benefit the educational supervisors as it provides a proposal to develop the skills of social studies female teachers in various teaching disciplines in the light of the digital revolution.

- The study makes recommendations that benefit the authors and open new horizons for future studies in education in the light of the digital revolution. 


\section{LIMITATIONS}

1- Temporal limitations: The study was applied during the first semester of the academic year 2016-2017.

2- Spatial limitations: It was limited to Asir area, Saudi Arabia.

3- Human limitations: It was applied to the social studies female teachers in Asir, Saudi Arabia.

4- Objective limitations: The study was interested in the training needs of the digital revolution to develop the skills of social studies female teachers and providing a proposal to consolidate their skills.

\section{DEFINITION OF TERMS}

\section{Training Needs}

The author identifies the training needs as the structure of the training industry. They express a range of changes and developments required in the experience and trends of individuals in order to meet the requirements of educational work and to face the challenges of the teacher in teaching the courses of social sciences in the light of the digital revolution.

\section{Digital Revolution}

The author defines the digital revolution as cognitive, communicative, and stylistic processes in the education and teaching of social sciences subjects, relying on the Internet and electronic devices, e.g. computers and smart phones.

\section{Skills}

The author defines skills as a set of behaviors and abilities of social sciences female teachers to accomplish the objectives of education in light of the digital revolution.

\section{THEORETICAL FRAMEWORK AND LITERATURE REVIEW}

Almaghrebi (2007) defines them as "the total changes and improvements required to be made in the information, skills, and attitudes of teachers in order to overcome problems with the course of work that prevent the achievement of the objectives and hinder progress and development on the strategic term".

They are a set of changes required to bring about the knowledge, skills, and trends of the individuals working in the organization to modify their behavior, develop the desired behavior that ensure their access to the productivity of performance, and eliminate the deficiencies in performance. Consequently, their effectiveness in work increases (Elshami, 2006).

Al-Otaibi (2015) argues that the need indicates "deficiencies and shortcomings, or contradictions in the work performed by individuals. Training ensures that this deficiency is complemented by a set of specific actions."

Identifying the training needs is the scientific input to solve many problems of teacher training by focusing on the preparation and planning of effective training programs derived from their needs. Therefore, the imbalances between the performance to be achieved, reality, and available training opportunities are analyzed." (Beaudoin, 2004; Tawfik, 2006).

\section{Importance of Identifying the Training Needs}

Elewa (2001) reports that the effectiveness of the training programs depends on identifying the training needs by recognizing the current and required levels of performance, identifying the training policies, and setting the training programs to achieve such policies. Identifying training needs is an important and decisive process for their effectiveness because:

1- It indicates that training is properly guided in the sub-processes.

2- It helps focus on good performance and accomplish the basic goal of training.

3- It indicates the target group, the type of training required, and the expected results.

4- Its neglecting or inaccuracy wastes effort, time, and money (Al-Ta'ani, 2009).

Given the importance of identifying the needs that translates the actual need into those areas where they feel a lack of knowledge, it may be useful to involve a number of relevant parties according to the level and location of the target trainees and the overall objective to be achieved. 


\section{Resources Used in Identifying the Training Needs}

- Trainee as the only person who feels his/her shortcomings more than others.

- Direct supervisor who supervises the trainee to identify his/her training needs.

- Expert specialist and consultant; a person belonging to an independent training or advisory body specialized in training and identifying the needs.

- Senior management (local or central) by virtue of the general supervision of the trainee and having periodic reports on the length of the period of work on site.

- Specialized training centers (i.e. specialized expert houses) that have long experience, techniques, and survey methods that qualify them to accurately define the needs. (National Center for Judicial Studies, 2016).

Accordingly, one or more of the following can contribute to the identification of training needs based on the trainee's opinion as the focus of the training process.

\section{Justifications for Teachers' Training}

According to Hassanien (2014), Alahmad (2005), and Clyton (2006), the training for in-service teachers aims to make efforts to change the teacher's behavior and develop his/her skills and abilities after joining the school. Inservice training programs are not limited to the new teachers but they cover all teachers, taking into account their differences. They may take many forms, such as training workshops, specific courses offered by higher education institutions, or courses offered by the local institutions in which they work. They are important to:

1- Set modern teaching strategies and advanced technologies in educational technology and e-learning environments.

2- Identify the necessary needs of teachers psychologically, socially, academically, culturally, and professionally.

3- Define the most important global developments in education and confronting the data of the digital age and the explosion of knowledge.

4- Handle the deficiencies and weaknesses in the teacher's preparation process.

Also, they equip them with:

5- Modern information in the field of specialization.

6- Basic skills associated with conducting educational action researches.

\section{Digital Revolution}

The impact of the digital revolution is manifested in all aspects of life, especially education, where many educational activities have emerged including smart schools, virtual classrooms, virtual education, e-learning, eadministration, and computerized schools. The traditional way in which the student and teacher go to the school on specific times has gone. Consequently, education is available anywhere and anytime (Hussein, 2009).

\section{Education in the Era of the Digital Revolution}

Future trends indicate that e-learning will impose itself on the educational systems that school becomes a source, not a place, of learning.

Newby et al. (2000) reported that education will involve teachers and students in the educational technology and integrate it to improve teaching and learning. In other words, significant changes in the learning process will occur. Their predictions came into reality. In the light of the current changes, the educational process is characterized with:

- Multiple sources of learning media through information networks.

- Active students learn collaboratively with each other and with more experienced members of the community to search for information and knowledge.

- Changing the teacher's role from "teacher" to "supervisor", helping students use new information tools.

- Education is sustainable and accessible to all and schools are learning centers for all.

- Using distance learning techniques that enable learners to learn from teachers at other sites. 


\section{The Role of Teacher in the Digital Revolution}

Some studies (e.g. Al-Ghareeb, 2009; Al-Halafawi, 2011; Al-Zahrani \& Ibrahim, 2012; Newby et al., 2000; Sultan, 2005) indicate that the nature of the roles of the teacher and student, in the digital age, change in a way that reflects the nature of modern educational environments and how to deal with them. Because of the transformation of education to virtual, educators expect a fundamental shift in the role of the teacher because:

- The teacher changes from a provider of information to a guide, trainer, and facilitator of learning.

- The teacher changes from a person who works individually to a member of a cooperative team.

- The teacher changes from a source of information to a consultant.

- Design of e-courses.

\section{The Essential Skills for the Teacher in Digital Revolution}

The roles imposed on teachers in the digital age require the availability of a number of skills that enable them to meet their requirements. Thus, they should have a set of skills including:

- Development of life skills management; the learner acquires from the teacher things related to the way of communication, management of dealing, and self-skills because there is a need for independent decisions under the name of life skills.

- Development of thinking skills; education has become a major goal of educational institutions that many countries have adopted this trend (i.e. using and management of educational technology) in their educational processes, including America, Singapore, Japan, and Malaysia. Therefore, the teacher of the digital age should be able to use, manage, and employ technology in education.

- Management of students' abilities in differentiated instruction; it aims to raise the level of all students, not only those who have problems in achievement (Alsaleh, 2015; Bernie \& Charles, 2013; Makrakis, 2005).

This coincides with the findings of Mohammed and Alharbi (2016), stressing that the use of new technology in education requires a set of skills that the teachers of the digital age should have. They are the ability to think critically, providing students with life skills, developing the higher skills of thinking, using and managing the educational technology, supporting knowledge economy, managing students' abilities through differential instruction.

Therefore, many studies were found to report the importance of identifying the training needs according to the current variables and the digital revolution. They stressed the importance of training teachers to meet these variables and requirements.

Aldalan (2004) identified the training needs of science teachers in the high stage in the Kingdom of Saudi Arabia in using the educational technologies from the perspective of science teachers and supervisors. The study also sought to identify the availability difficulties of educational technologies in this stage. It investigated the opinions of a sample of (825) teachers and (255) supervisors. It showed that there was a relationship between the availability and use of educational technology. Additionally, its most important difficulties were the lack of specialized staff. Accordingly, teachers lack the cognitive and theoretical aspects of the use of educational technologies. The supervisors agreed on the importance of employing teaching technologies in achieving the objectives of the curriculum.

Al-Dosari (2005) aimed at identifying the training needs of mathematics teachers in the high stage in the use of computers in teaching, and identifying the significance of statistical differences, if any, among the training needs of the participants. In order to achieve the objectives of the study, the author applied a questionnaire to a sample of (79) mathematics teachers of the high stage in Riyadh. The study concluded that while the most important training needs were (managing and organizing files in folders, using word processors to write the mathematical symbols, formulas, fractions, and bases), the least ones were (using the operating system to access information available on a local network, using of desktop publishing programs, and virtual reality applications). There were no statistically significant differences between the degree of the training need according to the teaching experience and the academic qualification.

Berecin-Rascon (2008) aimed to find out the perspectives of workers in the field of special education about their roles and the quality of training they need in this area. The population of the study comprised (48) special education teachers in Western Arizona. The study applied a questionnaire of (46) items to find out their views and needs on training and quality of preparation. It concluded that the most significant training needs the respondents disclosed included: Identifying the goals and contents of the individual educational plans, understanding the concepts of learning difficulties, improving communication with the employees of schools in pupils' services who have special educational needs, and training on the techniques and strategies of management and improvement of students' behavior. 
Table 1. Distribution of the participants according to the nature of work

\begin{tabular}{llcc}
\hline Personal data & Variables & Frequency & Percentage \\
\hline \multirow{2}{*}{ Nature of work } & Supervisor & 29 & 46.8 \\
\cline { 2 - 4 } Qualification & Teacher & 33 & 53.2 \\
\hline \multirow{3}{*}{ Years of experience } & Educational Bachelor & 52 & 83.9 \\
\cline { 2 - 4 } & Non-educational Bachelor & 10 & 16.1 \\
\hline & Less than 5 years & 12 & 19.4 \\
\cline { 2 - 4 } & From 5 to 10 years & 15 & 24.2 \\
\cline { 2 - 4 } & From 10 to 15 years & 17 & 27.4 \\
\cline { 2 - 4 } & More than 15 years & 62 & 18.0 \\
\hline
\end{tabular}

Nelson (2009) identified the most important needs and areas that private education teachers consider important for the development of their professional practices. The study also aimed to identify the most important activities to develop their skills and abilities. It applied a questionnaire to a sample of $(5,492)$ special education teachers in USA schools in the scholastic year (2003-2004). It concluded that special education teachers need to be trained on controlling and managing the behavior of students with learning difficulties in the classroom, using technology in education, and assessing students with learning disabilities, and Knowledge of educational curricula.

Amin (2010) aimed at investigating the reality of the teacher training program on the employment of educational technology in terms of objectives, content, stakeholders, and beneficiaries of the implementation stages. The study made a list of quality standards that must be met in the content of the teacher training programs to employ technology, including the International Computer Driving License (ICDL) and the employment of information and communication technology. It recommended that the content of these programs should be reviewed in light of the list of quality standards. Additionally, there should be communication and coordination between the Ministry of Education and colleges of teacher preparation and training so that teachers can use and employ the skills of educational technology.

Munoz and Towner (2012) aimed at developing a proposal on the use of the Internet in teacher training programs. The authors adopted the descriptive analytical approach. The research tool consisted of analyzing the services, tools, and applications used in the educational websites. The study concluded that websites, especially social media, can benefit students and teachers, but it is necessary to develop teaching methods as an alternative to the traditional ones in line with the nature of the social environment. Furthermore, teachers need to expand their educational portfolio. It recommended that experimental studies should be conducted to measure the effectiveness of e-learning communities that use social media.

\section{Commenting on Literature}

Literature tackled a set of objectives, of which identifying the training needs of teachers was the most important. It concluded that identifying the needs consolidate the abilities of teachers in their professional practices. Some studies investigated the training needs in the light of modern technologies.

The present study coincides with literature in various aspects, e.g. identifying the training needs. It agrees with some studies on identifying the training needs in the light of digital revolution. However, it disagrees with literature on other aspects, regarding guiding the training needs to develop the skills of female teachers in the light of digital revolution. Additionally, it seeks to develop a proposal to develop the skills of female teachers according to their training needs.

\section{PROCEDURES OF THE STUDY}

\section{Population}

The population comprised all social studies female teachers in Asir in the first semester of the academic year (2016/2017).

\section{Sampling}

The author tended to use the electronic questionnaire sent to a randomly selected sample of social studies female teachers. The respondents were (62) female teachers. Table 1 shows the personal features of the sample. 


\section{Tool of the Study}

After reviewing literature, the domains of the questionnaire were defined and formulated. In its preliminary form, the questionnaire was submitted to a group of specialists in education, curricula, and methods of instruction. In its final form, the questionnaire comprised (69) items on (6) main domains in addition to (2) domains that were separated into a set of sub-domains, as follows:

1- Teaching in the electronic environments, covering (planning- strategies- interaction).

2- Educational technology and activities, covering (educational technology-educational activities)

3- Skills of the digital teacher

4- Skills of action research

5- Using educational materials and resources

6- Evaluation

\section{Validity of the tool}

I. External validity

The tool was prepared based on the related literature. It was reviewed by a group of specialists in curricula and methods of teaching social studies and educational technology. It was prepared in its final form based on their opinions.

\section{Reliability}

Pearson correlation coefficients between the items and the total score of the domain calculated and ranged from (0.56 to 0.93$)$, all of which are statistically significant at (0.01).

The author measured the reliability of the tool using Cronbach's alpha, it ranged from (0.60: 0.89) in the questionnaire domains and $(0.96)$ at the level of $(0.01)$ for the whole questionnaire. It means that the questionnaire has a high degree of reliability.

\section{RESULTS AND DISCUSSION}

Results of the 1st question: What are the training needs in the light of the digital revolution of social studies female teachers regarding teaching in the electronic environments?

To answer the $1^{\text {st }}$ question, the author calculated frequencies, percentages, arithmetic means, standard deviations, and ranks of responses to the items of (teaching in the electronic environments) domain (i.e. planningteaching strategies- interaction), as shown in Table 2. 
Table 2. Statestical description of the items of teaching in the electronic environments (planning)

\begin{tabular}{|c|c|c|c|c|c|c|c|c|c|c|c|}
\hline \multirow{3}{*}{ No. } & \multirow{3}{*}{ Item } & \multicolumn{6}{|c|}{ Importance degree } & \multirow{3}{*}{$\begin{array}{l}\text { Arithmetic } \\
\text { mean }\end{array}$} & \multirow{3}{*}{$\begin{array}{l}\text { Standard } \\
\text { deviation }\end{array}$} & \multirow{3}{*}{ Ranking } & \multirow{3}{*}{ Importance } \\
\hline & & \multicolumn{2}{|c|}{$\begin{array}{c}\text { Not } \\
\text { important }\end{array}$} & \multicolumn{2}{|c|}{$\begin{array}{l}\text { Slightly } \\
\text { important }\end{array}$} & \multicolumn{2}{|c|}{ Important } & & & & \\
\hline & & Freq. & $\%$ & Freq. & $\%$ & Freq. & $\%$ & & & & \\
\hline 1 & Teaching planning & 1 & 1.6 & 11 & 17.7 & 50 & 80.6 & 2.79 & 0.45 & 1 & Important \\
\hline 2 & $\begin{array}{l}\text { Planning to situations } \\
\text { and experiences }\end{array}$ & 1 & 1.6 & 14 & 22.6 & 47 & 75.8 & 2.74 & 0.48 & 2 & Important \\
\hline 3 & $\begin{array}{l}\text { Formulation of the } \\
\text { teaching objectives }\end{array}$ & 3 & 4.8 & 16 & 25.8 & 43 & 69.4 & 2.65 & 0.58 & 3 & Important \\
\hline 6 & $\begin{array}{l}\text { Using technology in } \\
\text { teaching }\end{array}$ & 3 & 4.8 & 18 & 29 & 41 & 66.1 & 2.61 & 0.58 & 4 & Important \\
\hline 5 & $\begin{array}{l}\text { Preparing the digital } \\
\text { content }\end{array}$ & 4 & 6.5 & 17 & 27.4 & 41 & 66.1 & 2.60 & 0.61 & 5 & Important \\
\hline 9 & $\begin{array}{l}\text { Electronic assignments } \\
\text { and discussions }\end{array}$ & 4 & 6.5 & 17 & 27.4 & 41 & 66.1 & 2.60 & 0.61 & 6 & Important \\
\hline 4 & Design of e-courses & 2 & 3.2 & 22 & 35.5 & 38 & 61.3 & 2.58 & 0.56 & 7 & Important \\
\hline 8 & $\begin{array}{l}\text { Design the evaluative } \\
\text { tests and feedback }\end{array}$ & 10 & 16.1 & 32 & 51.6 & 20 & 32.3 & 2.16 & 0.68 & 8 & $\begin{array}{c}\text { Slightly } \\
\text { important }\end{array}$ \\
\hline 7 & $\begin{array}{l}\text { Suggesting supporting } \\
\text { cognitive methods }\end{array}$ & 10 & 16.1 & 36 & 58.1 & 16 & 25.8 & 2.10 & 0.65 & 9 & $\begin{array}{l}\text { Slightly } \\
\text { important }\end{array}$ \\
\hline \multicolumn{8}{|c|}{ General arithmetic mean } & 2.54 & 0.43 & \multicolumn{2}{|c|}{ Important } \\
\hline
\end{tabular}

Table 2 shows that the participants mostly agreed on (planning) domain, where the arithmetic mean was (2.10 to 2.79) in the second and third categories indicating (slightly important/important). The general arithmetic mean reached (2.54 out of 3). It is noted that social studies female teachers and supervisors believe that (teaching in the electronic environments) is one of the most important training needs in the age of the digital revolution. Furthermore, the responses of the participants to item (1) "i.e. teaching planning" were ranked first, taking "important" category with an arithmetic mean of (2.79) and a standard deviation of (0.45). The responses to item (2) "i.e. planning to situations and experiences" were ranked second, taking "important" category with an arithmetic mean of (2.74) and a standard deviation of (0.48). Finally, the responses to item (3) "i.e. formulating teaching objectives" were ranked third, taking "important" category with an arithmetic mean of (2.65) and a standard deviation of (0.58).

The author believed that planning lessons is one of the most important processes of education and organizing the educational situation as curricula continually evolve. Accordingly, the training needs were high on the items of planning domain, where the relative weight of the total score was $(84.67 \%)$, indicating the importance of the related training needs. The female teachers can use plans, tools, and teaching experiences based on modern technology as there are various effective attitudes related to using and employing modern teaching strategies.

Table 3 shows that the respondents mostly agreed on (teaching strategies) domain, where the arithmetic mean was (2.39 to 2.85 ) in the third category (i.e. important). The general arithmetic mean was (2.62 out of 3). Social studies female teachers believed that (teaching implementation) was one of the most important training needs in the age of the digital revolution. The most significant strategies were peer learning, learning circles, learning from situations, active learning, and virtual learning. 
Table 3. Responses of the participants to the items of teaching in the electronic environments (teaching strategies)

\begin{tabular}{|c|c|c|c|c|c|c|c|c|c|c|c|}
\hline \multirow{3}{*}{ No. } & \multirow{3}{*}{ Item } & \multicolumn{6}{|c|}{ Importance degree } & \multirow{3}{*}{$\begin{array}{l}\text { Arithmetic } \\
\text { mean }\end{array}$} & \multirow{3}{*}{$\begin{array}{l}\text { Standard } \\
\text { deviation }\end{array}$} & \multirow{3}{*}{ Ranking } & \multirow{3}{*}{ Importance } \\
\hline & & \multicolumn{2}{|c|}{$\begin{array}{c}\text { Not } \\
\text { important }\end{array}$} & \multicolumn{2}{|c|}{$\begin{array}{c}\text { Slightly } \\
\text { important }\end{array}$} & \multicolumn{2}{|c|}{ Important } & & & & \\
\hline & & Freq. & $\%$ & Freq. & $\%$ & Freq. & $\%$ & & & & \\
\hline 2 & Education circles strategy & 0 & 0 & 9 & 14.5 & 53 & 85.5 & 2.85 & 0.36 & 1 & Important \\
\hline 9 & $\begin{array}{l}\text { Mass questionnaire on } \\
\text { the web }\end{array}$ & 2 & 3.2 & 8 & 12.9 & 52 & 83.9 & 2.81 & 0.47 & 2 & Important \\
\hline 4 & Active learning & 0 & 0 & 14 & 22.6 & 48 & 77.4 & 2.77 & 0.42 & 3 & Important \\
\hline 3 & Learning from situations & 1 & 1.6 & 14 & 22.6 & 47 & 75.8 & 2.74 & 0.48 & 4 & Important \\
\hline 1 & Peer education & 8 & 12.9 & 9 & 14.5 & 45 & 72.6 & 2.60 & 0.71 & 5 & Important \\
\hline 6 & Differentiated instruction & 4 & 6.5 & 18 & 29 & 40 & 64.5 & 2.58 & 0.62 & 6 & Important \\
\hline 5 & Virtual Learning & 7 & 11.3 & 22 & 35.5 & 33 & 53.2 & 2.42 & 0.69 & 7 & Important \\
\hline 7 & $\begin{array}{l}\text { Cooperative competitive } \\
\text { learning }\end{array}$ & 9 & 14.5 & 20 & 32.3 & 33 & 53.2 & 2.39 & 0.73 & 8 & Important \\
\hline 8 & $\begin{array}{l}\text { Integrated Learning } \\
\text { Curve }\end{array}$ & 9 & 14.5 & 20 & 32.3 & 33 & 53.2 & 2.39 & 0.73 & 9 & Important \\
\hline & Gene & ari & ic & & & & & 2.62 & 0.39 & & rtant \\
\hline
\end{tabular}

Table 4. Responses of the participants to the items of teaching in the electronic environments (Interaction)

\begin{tabular}{|c|c|c|c|c|c|c|c|c|c|c|c|}
\hline \multirow{3}{*}{ No. } & \multirow{3}{*}{ Item } & \multicolumn{6}{|c|}{ Importance degree } & \multirow{3}{*}{$\begin{array}{l}\text { Arithmetic } \\
\text { mean }\end{array}$} & \multirow{3}{*}{$\begin{array}{l}\text { Standard } \\
\text { deviation }\end{array}$} & \multirow{3}{*}{ Ranking } & \multirow{3}{*}{ Importance } \\
\hline & & \multicolumn{2}{|c|}{$\begin{array}{c}\text { Not } \\
\text { important }\end{array}$} & \multicolumn{2}{|c|}{$\begin{array}{c}\text { Slightly } \\
\text { important }\end{array}$} & \multicolumn{2}{|c|}{ Important } & & & & \\
\hline & & Freq. & $\%$ & Freq. & $\%$ & Freq. & $\%$ & & & & \\
\hline 1 & Concept of interaction & 2 & 3.2 & 10 & 16.1 & 50 & 80.6 & 2.77 & 0.49 & 1 & Important \\
\hline 3 & $\begin{array}{l}\text { Learner-teacher } \\
\text { interaction }\end{array}$ & 1 & 1.6 & 14 & 22.6 & 47 & 75.8 & 2.74 & 0.48 & 2 & Important \\
\hline 4 & $\begin{array}{l}\text { Teacher-teacher } \\
\text { interaction }\end{array}$ & 3 & 4.8 & 10 & 16.1 & 49 & 79 & 2.74 & 0.54 & 3 & Important \\
\hline 7 & $\begin{array}{l}\text { Interaction with the } \\
\text { learning environment }\end{array}$ & 2 & 3.2 & 14 & 22.6 & 46 & 74.2 & 2.71 & 0.52 & 4 & Important \\
\hline 8 & Human social interaction & 1 & 1.6 & 16 & 25.8 & 45 & 72.6 & 2.71 & 0.49 & 5 & Important \\
\hline 5 & $\begin{array}{l}\text { Interaction with the } \\
\text { content }\end{array}$ & 2 & 3.2 & 15 & 24.2 & 45 & 72.6 & 2.69 & 0.53 & 6 & Important \\
\hline 6 & $\begin{array}{l}\text { Interaction between } \\
\text { learners }\end{array}$ & 1 & 1.6 & 17 & 27.4 & 44 & 71 & 2.69 & 0.50 & 7 & Important \\
\hline 2 & Interaction styles & 3 & 4.8 & 14 & 22.6 & 45 & 72.6 & 2.68 & 0.57 & 8 & Important \\
\hline \multicolumn{8}{|c|}{ General arithmetic mean } & 2.72 & 0.44 & & portant \\
\hline
\end{tabular}

Furthermore, the responses of the participants to item (2) "i.e. education circles strategy" were ranked first, taking "important" category with an arithmetic mean of (2.85) and a standard deviation of (0.36). The responses to item (9) "i.e. mass questionnaire on the web" were ranked second, taking "important" category with an arithmetic mean of (2.81) and a standard deviation of (0.47). Finally, the responses to item (4) "i.e. active learning" were ranked third, taking "important" category with an arithmetic mean of (2.77) and a standard deviation of (0.42).

The author believed that the most important training needs were related to teaching strategies as it is a continually evolving process. In addition, learning theories are based on considering the features of the target group of students and the environment that became mainly digital. Accordingly, all the training needs were high with a relative weight of $(87.33 \%)$.

Table 4 shows that the respondents mostly agreed on (interaction) domain, where the arithmetic mean was (2.68 to 2.77 ) in the third category (i.e. important); the general arithmetic mean scored (2.72 out of 3). Social studies female teachers believed that (interaction) was one of the most important training needs in the age of the digital revolution that could be implemented through the concept of interaction with the content, teacher-learner interaction, interaction with the learning environment, teacher-teacher interaction, and social interaction.

Furthermore, the responses of the participants to item (1) "i.e. the concept of interaction" were ranked first, taking "important" category with an arithmetic mean of (2.77) and a standard deviation of (0.49). The responses to item (3) "i.e. teacher-learner interaction" were ranked second, taking "important" category with an arithmetic mean of (2.74) and a standard deviation of (0.48). Finally, the responses to item (4) "i.e. teacher-teacher interaction" were ranked third, taking "important" category with an arithmetic mean of (2.74) and a standard deviation of (0.54). The 
Table 5. Responses of the participants to the items of technology and activities (educational technology)

\begin{tabular}{|c|c|c|c|c|c|c|c|c|c|c|c|}
\hline \multirow{3}{*}{ No. } & \multirow{3}{*}{ Item } & \multicolumn{6}{|c|}{ Importance degree } & \multirow{3}{*}{$\begin{array}{l}\text { Arithmetic } \\
\text { mean }\end{array}$} & \multirow{3}{*}{$\begin{array}{l}\text { Standard } \\
\text { deviation }\end{array}$} & \multirow{3}{*}{ Ranking } & \multirow{3}{*}{ Importance } \\
\hline & & \multicolumn{2}{|c|}{$\begin{array}{c}\text { Not } \\
\text { important }\end{array}$} & \multicolumn{2}{|c|}{$\begin{array}{c}\text { Slightly } \\
\text { important }\end{array}$} & \multicolumn{2}{|c|}{ Important } & & & & \\
\hline & & Freq. & $\%$ & Freq. & $\%$ & Freq. & $\%$ & & & & \\
\hline 10 & $\begin{array}{l}\text { Modern trends in } \\
\text { educational technology }\end{array}$ & 2 & 3.2 & 8 & 12.9 & 52 & 83.9 & 2.81 & 0.47 & 1 & Important \\
\hline 4 & $\begin{array}{l}\text { Using information } \\
\text { technology and the } \\
\text { Internet }\end{array}$ & 2 & 3.2 & 9 & 14.5 & 51 & 82.3 & 2.79 & 0.48 & 2 & Important \\
\hline 8 & $\begin{array}{l}\text { Design presentations in } \\
\text { e-learning }\end{array}$ & 2 & 3.2 & 11 & 17.7 & 49 & 79 & 2.76 & 0.50 & 3 & Important \\
\hline 1 & $\begin{array}{l}\text { The concept and choice } \\
\text { of educational } \\
\text { technology }\end{array}$ & 2 & 3.2 & 12 & 19.4 & 48 & 77.4 & 2.74 & 0.51 & 4 & Important \\
\hline 3 & Arithmetic simulation & 2 & 3.2 & 14 & 22.6 & 46 & 74.2 & 2.71 & 0.52 & 5 & Important \\
\hline 6 & $\begin{array}{l}\text { Maintenance of } \\
\text { educational technology }\end{array}$ & 3 & 4.8 & 18 & 29 & 41 & 66.1 & 2.61 & 0.58 & 6 & Important \\
\hline 2 & Design of e-learning & 4 & 6.5 & 18 & 29 & 40 & 64.5 & 2.58 & 0.62 & 7 & Important \\
\hline 7 & $\begin{array}{l}\text { Design of the educational } \\
\text { programs }\end{array}$ & 2 & 3.2 & 22 & 35.5 & 38 & 61.3 & 2.58 & 0.56 & 8 & Important \\
\hline 9 & $\begin{array}{l}\text { Quality of the } \\
\text { educational programs }\end{array}$ & 4 & 6.5 & 18 & 29 & 40 & 64.5 & 2.58 & 0.62 & 9 & Important \\
\hline 5 & $\begin{array}{l}\text { Evaluation of educational } \\
\text { technology }\end{array}$ & 4 & 6.5 & 21 & 33.9 & 37 & 59.7 & 2.53 & 0.62 & 10 & Important \\
\hline \multicolumn{8}{|c|}{ General arithmetic mean } & 2.67 & 0.43 & & portant \\
\hline
\end{tabular}

author argued that classroom interaction was one of the most important educational aspects that improve classroom practices of the teachers. Therefore, the training needs were high achieving $(90.667 \%)$.

Results of the $2^{\text {nd }}$ question: What are the training needs in the light of the digital revolution of social studies female teachers regarding educational technology and activities?

To answer the $2^{\text {nd }}$ question, the author calculated frequencies, percentages, arithmetic means, standard deviations, and ranks of responses to the items of (educational technology- educational activities) domain, as shown in Table 5.

Table 5 shows that the participants mostly agreed on (management of educational technology) domain, where the arithmetic mean was (2.53 to 2.81 ) in the third category (i.e. important); the general arithmetic mean was (2.67 out of 3).

Furthermore, the responses of the participants to item (10) "i.e. modern trends in educational technology" were ranked first, taking "important" category with an arithmetic mean of (2.81) and a standard deviation of (0.47). The responses to item (4) "i.e. using educational technology and the Internet" were ranked second, taking "important" category with an arithmetic mean of (2.79) and a standard deviation of (0.48). Finally, the responses to item (8) "i.e. design of presentations in e-learning" were ranked third, taking "important" category with an arithmetic mean of (2.76) and a standard deviation of (0.50).

The author argued that the study is interested in the digital revolution. Consequently, the training needs related to the digital revolution were high, especially in educational technology. She believed that modern teaching strategies and technologies fortify teachers in the face of courses' development and the maximization of school objectives. They achieved a high degree of $(89 \%)$.

Table 6 shows that the respondents mostly agreed on (educational activities) domain, where the arithmetic mean scored (2.55 to 2.76) in the third category (i.e. important); the general arithmetic mean was (2.67 out of 3). Social studies female teachers believed that (educational activities) was one of the most important training needs in the age of the digital revolution that could be implemented through choosing the educational activities, activities according to the educational experience, design of the educational activities, evaluation of the educational activities, building the educational activities, and implementation of the educational activities. 
Table 6. Responses of the participants to the items of technology and activities (educational activities)

\begin{tabular}{|c|c|c|c|c|c|c|c|c|c|c|c|}
\hline \multirow{3}{*}{ No. } & \multirow{3}{*}{ Item } & \multicolumn{6}{|c|}{ Importance degree } & \multirow{3}{*}{$\begin{array}{l}\text { Arithmetic } \\
\text { mean }\end{array}$} & \multirow{3}{*}{$\begin{array}{l}\text { Standard } \\
\text { deviation }\end{array}$} & \multirow{3}{*}{ Ranking } & \multirow{3}{*}{ Importance } \\
\hline & & \multicolumn{2}{|c|}{$\begin{array}{c}\text { Not } \\
\text { important }\end{array}$} & \multicolumn{2}{|c|}{$\begin{array}{l}\text { Slightly } \\
\text { important }\end{array}$} & \multicolumn{2}{|c|}{ Important } & & & & \\
\hline & & Freq. & $\%$ & Freq. & $\%$ & Freq. & $\%$ & & & & \\
\hline 3 & $\begin{array}{l}\text { Selecting the educational } \\
\text { activities }\end{array}$ & 2 & 3.2 & 11 & 17.7 & 49 & 79 & 2.76 & 0.50 & 1 & Important \\
\hline 8 & $\begin{array}{l}\text { Activities according to the } \\
\text { educational experience }\end{array}$ & 2 & 3.2 & 13 & 21 & 47 & 75.8 & 2.73 & 0.52 & 2 & Important \\
\hline 1 & $\begin{array}{l}\text { Design of the educational } \\
\text { activities }\end{array}$ & 2 & 3.2 & 14 & 22.6 & 46 & 74.2 & 2.71 & 0.52 & 3 & Important \\
\hline 5 & $\begin{array}{l}\text { Evaluation of the } \\
\text { educational activities }\end{array}$ & 3 & 4.8 & 14 & 22.6 & 45 & 72.6 & 2.68 & 0.57 & 4 & Important \\
\hline 2 & $\begin{array}{l}\text { Types of the educational } \\
\text { activities }\end{array}$ & 2 & 3.2 & 17 & 27.4 & 43 & 69.4 & 2.66 & 0.54 & 5 & Important \\
\hline 4 & $\begin{array}{l}\text { Implementation of the } \\
\text { educational activities }\end{array}$ & 3 & 4.8 & 16 & 25.8 & 43 & 69.4 & 2.65 & 0.58 & 6 & Important \\
\hline 7 & Virtual libraries & 6 & 9.7 & 13 & 21 & 43 & 69.4 & 2.60 & 0.66 & 7 & Important \\
\hline 6 & $\begin{array}{l}\text { Building the educational } \\
\text { activities }\end{array}$ & 6 & 9.7 & 16 & 25.8 & 40 & 64.5 & 2.55 & 0.67 & 8 & Important \\
\hline \multicolumn{8}{|c|}{ General arithmetic mean } & 2.67 & 0.46 & & portant \\
\hline
\end{tabular}

Table 7. Responses of the participants to (skills of the digital teacher) domain

\begin{tabular}{|c|c|c|c|c|c|c|c|c|c|c|c|}
\hline \multirow{3}{*}{ No. } & \multirow{3}{*}{ Item } & \multicolumn{6}{|c|}{ Importance degree } & \multirow{3}{*}{$\begin{array}{l}\text { Arithmetic } \\
\text { mean }\end{array}$} & \multirow{3}{*}{$\begin{array}{l}\text { Standard } \\
\text { deviation }\end{array}$} & \multirow{3}{*}{ Ranking } & \multirow{3}{*}{ Importance } \\
\hline & & \multicolumn{2}{|c|}{$\begin{array}{c}\text { Not } \\
\text { important }\end{array}$} & \multicolumn{2}{|c|}{$\begin{array}{l}\text { Slightly } \\
\text { important }\end{array}$} & \multicolumn{2}{|c|}{ Important } & & & & \\
\hline & & Freq. & $\%$ & Freq. & $\%$ & Freq. & $\%$ & & & & \\
\hline 1 & Self-management skills & 0 & 0 & 8 & 12.9 & 54 & 87.1 & 2.87 & 0.34 & 1 & Important \\
\hline 5 & Higher thinking skills & 0 & 0 & 13 & 21 & 49 & 79 & 2.79 & 0.41 & 2 & Important \\
\hline 3 & Communication skills & 1 & 1.6 & 13 & 21 & 48 & 77.4 & 2.76 & 0.47 & 3 & Important \\
\hline 2 & Human management skills & 1 & 1.6 & 14 & 22.6 & 47 & 75.8 & 2.74 & 0.48 & 4 & Important \\
\hline 4 & $\begin{array}{l}\text { Cooperative and social } \\
\text { skills }\end{array}$ & 1 & 1.6 & 15 & 24.2 & 46 & 74.2 & 2.73 & 0.48 & 5 & Important \\
\hline \multicolumn{8}{|c|}{ General arithmetic mean } & 2.78 & 0.37 & & portant \\
\hline
\end{tabular}

Additionally, the responses of the participants to item (3) "i.e. choosing the educational activities" were ranked first, taking "important" category with an arithmetic mean of (2.76) and a standard deviation of (0.50). The responses to item (8) "i.e. activities according to the educational experience" were ranked second, taking "important" category with an arithmetic mean of (2.73) and a standard deviation of (0.52). Finally, the responses to item (1) "i.e. design of the educational activities" were ranked third, taking "important" category with an arithmetic mean of (2.71) and a standard deviation of (0.52).

Results of the $3^{\text {rd }}$ question: What are the training needs in the light of the digital revolution of social studies female teachers regarding the digital teacher?

To answer the $3^{\text {rd }}$ question, the author calculated frequencies, percentages, arithmetic means, standard deviations, and ranks of responses to the items of (skills of the digital teacher) domain, as shown in Table 7.

Table 7 shows that the participants mostly agreed on (development of the digital teacher skills) domain, where the arithmetic mean was (2.73 to 2.87 ) in the third category (i.e. important); the general arithmetic mean achieved (2.78 out of 3$)$.

In addition, the responses of the participants to item (1) "i.e. self-management" were ranked first, taking "important" category with an arithmetic mean of (2.87) and a standard deviation of (0.34). The responses to item (5) "i.e. higher thinking skills" were ranked second, taking "important" category with an arithmetic mean of (2.79) and a standard deviation of (0.41). Finally, the responses to item (3) "i.e. communication skills" were ranked third, taking "important" category with an arithmetic mean of (2.76) and a standard deviation of (0.47).

Results of the $4^{\text {th }}$ question: What are the training needs in the light of the digital revolution of social studies female teachers regarding the skills of action research?

To answer the $4^{\text {th }}$ question, the author calculated frequencies, percentages, arithmetic means, standard deviations, and ranks of responses to the items of (development of of action research skills) domain, as shown in Table 8 . 
Table 8. Responses of the participants to (development of of action research skills) domain

\begin{tabular}{|c|c|c|c|c|c|c|c|c|c|c|c|}
\hline \multirow{3}{*}{ No. } & \multirow{3}{*}{ Item } & \multicolumn{6}{|c|}{ Importance degree } & \multirow{3}{*}{$\begin{array}{l}\text { Arithmetic } \\
\text { mean }\end{array}$} & \multirow{3}{*}{$\begin{array}{l}\text { Standard } \\
\text { deviation }\end{array}$} & \multirow{3}{*}{ Ranking } & \multirow{3}{*}{ Importance } \\
\hline & & \multicolumn{2}{|c|}{$\begin{array}{c}\text { Not } \\
\text { important }\end{array}$} & \multicolumn{2}{|c|}{$\begin{array}{c}\text { Slightly } \\
\text { important }\end{array}$} & \multicolumn{2}{|c|}{ Important } & & & & \\
\hline & & Freq. & $\%$ & Freq. & $\%$ & Freq. & $\%$ & & & & \\
\hline 3 & $\begin{array}{l}\text { Skills and steps of action } \\
\text { research }\end{array}$ & 2 & 3.2 & 7 & 11.3 & 53 & 85.5 & 2.82 & 0.46 & 1 & Important \\
\hline 2 & $\begin{array}{l}\text { Concept and features of } \\
\text { action research }\end{array}$ & 3 & 4.8 & 11 & 17.7 & 48 & 77.4 & 2.73 & 0.55 & 2 & Important \\
\hline 1 & $\begin{array}{l}\text { Categorization of the } \\
\text { educational problems } \\
\text { according to field }\end{array}$ & 5 & 8.1 & 14 & 22.6 & 43 & 69.4 & 2.61 & 0.64 & 3 & Important \\
\hline 4 & $\begin{array}{l}\text { Skills of actions' } \\
\text { implementation }\end{array}$ & 4 & 6.5 & 18 & 29 & 40 & 64.5 & 2.58 & 0.62 & 4 & Important \\
\hline 5 & $\begin{array}{l}\text { Evaluating the action } \\
\text { research and report } \\
\text { writing }\end{array}$ & 6 & 9.7 & 16 & 25.8 & 40 & 64.5 & 2.55 & 0.67 & 5 & Important \\
\hline & Gene & al arith & tic $n$ & an & & & & 2.66 & 0.51 & & ortant \\
\hline
\end{tabular}

Table 9. Responses of the participants to (using educational materials and resources) domain

\begin{tabular}{|c|c|c|c|c|c|c|c|c|c|c|c|}
\hline \multirow{3}{*}{ No. } & \multirow{3}{*}{ Item } & \multicolumn{6}{|c|}{ Importance degree } & \multirow{3}{*}{$\begin{array}{l}\text { Arithmetic } \\
\text { mean }\end{array}$} & \multirow{3}{*}{$\begin{array}{l}\text { Standard } \\
\text { deviation }\end{array}$} & \multirow{3}{*}{\multicolumn{2}{|c|}{ Ranking Importance }} \\
\hline & & \multicolumn{2}{|c|}{$\begin{array}{l}\text { Not } \\
\text { important }\end{array}$} & \multicolumn{2}{|c|}{$\begin{array}{l}\text { Slightly } \\
\text { important }\end{array}$} & \multicolumn{2}{|c|}{ Important } & & & & \\
\hline & & Freq. & $\%$ & Freq. & $\%$ & Freq. & $\%$ & & & & \\
\hline 2 & E-maps & 0 & 0 & 7 & 11.3 & 55 & 88.7 & 2.89 & 0.32 & 1 & Important \\
\hline 1 & Using interactive books & 4 & 6.5 & 10 & 16.1 & 48 & 77.4 & 2.71 & 0.58 & 2 & Important \\
\hline 5 & $\begin{array}{l}\text { Social media on the } \\
\text { Internet }\end{array}$ & 4 & 6.5 & 17 & 27.4 & 41 & 66.1 & 2.60 & 0.61 & 3 & Important \\
\hline 4 & E-storage means & 5 & 8.1 & 16 & 25.8 & 41 & 66.1 & 2.58 & 0.64 & 4 & Important \\
\hline 3 & E-boards & 3 & 4.8 & 26 & 41.9 & 33 & 53.2 & 2.48 & 0.59 & 5 & Important \\
\hline \multicolumn{2}{|c|}{ General arithmetic mean } & & & & & & & 2.65 & 0.35 & & \\
\hline
\end{tabular}

Table 8 shows that the participants mostly agreed on (development of action research skills) domain, where the arithmetic mean was (2.55 to 2.82) in the third category (important); the general arithmetic mean scored (2.66 out of 3). It is reported that social studies female teachers report that (development of action research skills) is one of the most important training needs in the digital age, including categorization of the educational problems according to the field, concept and features of action research, skills and steps of action research, evaluation of action research, and report writing.

Furthermore, the responses of the participants to item (3) "i.e. skills and steps of action research" were ranked first, taking "important" category with an arithmetic mean of (2.82) and a standard deviation of (0.46). The responses to item (2) "i.e. concept and features of action research" were ranked second, taking "important" category with an arithmetic mean of (2.73) and a standard deviation of (0.55). Finally, the responses to item (1) "i.e. categorization of educational problems according to the field" were ranked third, taking "important" category with an arithmetic mean of (2.61) and a standard deviation of (0.64). The table shows that the relative weight of the total score was high; $(88.67 \%)$. The author reports that action research is one of the most important means that a teacher can adopt in evaluating performance and the means and tools of performance development. More effective and competent teaching strategies could be introduced to develop students' skills and abilities.

Results of the 5th question: What are the training needs in the light of the digital revolution of social studies female teachers regarding learning materials and resources?

To answer the $5^{\text {th }}$ question, the author calculated frequencies, percentages, arithmetic means, standard deviations, and ranks of responses to the items of (using educational materials and learning resources in teaching social studies) domain, as shown in Table 9.

Table 9 shows that the respondents mostly agreed on (using educational materials and learning resources) domain, where the arithmetic mean was (2.48 to 2.89) in the third category (i.e. important). The general arithmetic mean achieved (2.65 out of 3 ). Social studies female teachers argued that (using educational materials and learning resources in teaching social studies) was one of the most important training needs in the age of the digital revolution that could be implemented via e-maps, interactive books, social media, e-storage means, and e-boards. 
Table 10. Responses of the participants to (evaluation) domain

\begin{tabular}{|c|c|c|c|c|c|c|c|c|c|c|c|}
\hline \multirow{3}{*}{ No. } & \multirow{3}{*}{ Item } & \multicolumn{6}{|c|}{ Importance degree } & \multirow{3}{*}{$\begin{array}{l}\text { Arithmetic } \\
\text { mean }\end{array}$} & \multirow{3}{*}{$\begin{array}{l}\text { Standard } \\
\text { deviation }\end{array}$} & \multirow{3}{*}{ Ranking } & \multirow{3}{*}{ Importance } \\
\hline & & \multicolumn{2}{|c|}{$\begin{array}{c}\text { Not } \\
\text { important }\end{array}$} & \multicolumn{2}{|c|}{$\begin{array}{l}\text { Slightly } \\
\text { important }\end{array}$} & \multicolumn{2}{|c|}{ Significant } & & & & \\
\hline & & Freq. & $\%$ & Freq. & $\%$ & Freq. & $\%$ & & & & \\
\hline 1 & $\begin{array}{l}\text { The concept and } \\
\text { objectives of evaluation }\end{array}$ & 1 & 1.6 & 9 & 14.5 & 52 & 83.9 & 2.82 & 0.43 & 1 & Important \\
\hline 3 & Methods of evaluation & 0 & 0 & 13 & 21 & 49 & 79 & 2.79 & 0.41 & 2 & Important \\
\hline 4 & Self-evaluation & 1 & 1.6 & 11 & 17.7 & 50 & 80.6 & 2.79 & 0.45 & 3 & Important \\
\hline 7 & $\begin{array}{l}\text { Evaluation of cooperative } \\
\text { work }\end{array}$ & 0 & 0 & 13 & 21 & 49 & 79 & 2.79 & 0.41 & 4 & Important \\
\hline 9 & $\begin{array}{l}\text { Designing the tools of } \\
\text { evaluation }\end{array}$ & 1 & 1.6 & 11 & 17.7 & 50 & 80.6 & 2.79 & 0.45 & 5 & Important \\
\hline 8 & Feedback & 2 & 3.2 & 10 & 16.1 & 50 & 80.6 & 2.77 & 0.49 & 6 & Important \\
\hline 10 & Total evaluation & 3 & 4.8 & 8 & 12.9 & 51 & 82.3 & 2.77 & 0.53 & 7 & Important \\
\hline 6 & $\begin{array}{l}\text { Benefiting from the } \\
\text { results of evaluation }\end{array}$ & 1 & 1.6 & 13 & 21 & 48 & 77.4 & 2.76 & 0.47 & 8 & Important \\
\hline 5 & Stages of evaluation & 0 & 0 & 19 & 30.6 & 43 & 69.4 & 2.69 & 0.46 & 9 & Important \\
\hline 2 & $\begin{array}{l}\text { Difference between } \\
\text { measurement and } \\
\text { evaluation }\end{array}$ & 3 & 4.8 & 15 & 24.2 & 44 & 71 & 2.66 & 0.57 & 10 & Important \\
\hline & Gene & al arith & etic & ean & & & & 2.76 & 0.38 & & portant \\
\hline
\end{tabular}

In addition, the responses of the participants to item (2) "i.e. e-maps" were ranked first, taking "important" category with an arithmetic mean of (2.89) and a standard deviation of (0.32). The responses to item (1) "i.e. using interactive books" were ranked second, taking "important" category with an arithmetic mean of (2.71) and a standard deviation of (0.58). Finally, the responses to item (5) "i.e. social media on the web" were ranked third, taking "important" category with an arithmetic mean of (2.60) and a standard deviation of (0.61).

The table shows that the relative weight achieved $(88.33 \%)$ which was high, indicating that the digital revolution needs multiple resources and educational materials that achieve the educational objectives. Consequently, the training needs of teachers in the field were high because the digital revolution was reflected on the size and type of these sources.

Results of the $6^{\text {th }}$ question: What are the training needs in the light of the digital revolution of social studies female teachers regarding evaluation?

To answer the $6^{\text {th }}$ question, the author calculated frequencies, percentages, arithmetic means, standard deviations, and ranks of responses to the items of (evaluation of learning outcomes) domain, as shown in Table 10.

Table 10 shows that the respondents mostly agreed on (evaluating the educational outcomes) domain, where the arithmetic mean was (2.66 to 2.82) in the third category i.e. (important), the general arithmetic mean was (2.76) out of (3); social studies female teachers believed that (evaluating the educational outcomes) was one of the most important training needs in the age of the digital revolution that could be implemented through the concept of evaluation, difference between measurement and evaluation, evaluation methods, self-evaluation, cooperative evaluation, designing evaluation tools, and feedback.

Additionally, the responses of the participants to item (1) "i.e. the concept of evaluation" were ranked first, taking "important" category with an arithmetic mean of (2.82) and a standard deviation of (0.43). The responses to item (3) "i.e. evaluation styles" were ranked second, taking "important" category with an arithmetic mean of (2.79) and a standard deviation of (0.41). The responses to item (4) "i.e. self-evaluation" were ranked third, taking "important" category with an arithmetic mean of (2.79) and a standard deviation of (0.45).

The author argued that evaluation is one of the most important principles of educational work. It is the optimum way to measure the effectiveness of educational processes as evaluation requires continuous development, especially in the light of the digital revolution. Consequently, training critically needs high evaluation tools.

A proposal to train the female teachers according to the training needs in the light of the digital revolution:

The author analyzed data. A set of results were concluded, the most important of which were the high level of training needs in all domains. Accordingly, a proposal was developed and reviewed by a group of reviewers to be created in its final form.

\section{Philosophy of the Program}

The proposal is based on a philosophy and main principles that are displayed, as follows: 
- Functionality of the proposal according to the training needs of social studies female teachers to develop their skills in the light of the digital revolution.

- Reality of the proposal that is related to the nature of female teachers' performance, styles, and actions.

- Diversity of the experiences and alternatives of the proposal along with comprehensiveness, balance, and integration between the various aspects of the provided experiences.

- Diversity of styles, materials, and activities that consider the individual differences of the female trainees.

- Ultimate benefit from the inputs of self-learning because literature reflects its success and appropriateness to achieve the objectives of the study.

\section{Sources of the Proposal}

The preparation of the proposal was based on:

1- The questionnaire through which the training needs from the perspective of female teachers were identified.

2- These features should be considered when developing the proposal:

- Years of experience

- Nature of work

- Qualification

- Training courses

- Community features

- Training needs in the era of the digital revolution

- Modern trends in training

\section{Aim of the Proposal}

The proposal aims to develop the skills of female teachers and improve teaching performance in line with the digital revolution that affected teaching and its methods. When implementing the proposal, this objective should be transferred into a set of behavioral objectives of the training needs.

\section{Content of the Proposal}

The content of the proposal was based on its objective. In other words, the objectives are accomplished through the content as the content is created according to the training needs identified in the questionnaire that was applied to the female teachers. They will be detailed objectives that the proposal attempts to achieve. Furthermore, certain issues shall be considered when selecting the content, including:

- Soundness and accuracy of the material

- Simplicity of the items

- Continuous stage evaluation; no progress among the items of the proposal is achieved without mastering the former items.

- Appropriateness of the content to the trainees' level regarding expansion and depth

\section{Design of the Proposal}

The proposal takes the form of modules, each of which includes the following items:

1. Title

2. Introduction

3. Objectives

4. Content

5. Exercises and activities

6. Pre-and post-tests

7. Producing the educational materials and means of presentations, video clips, photographs, sound recording, e-maps, and drawing. Then, they are all entered to the computer to burn the CDs that contain the training programs of the female teachers. 


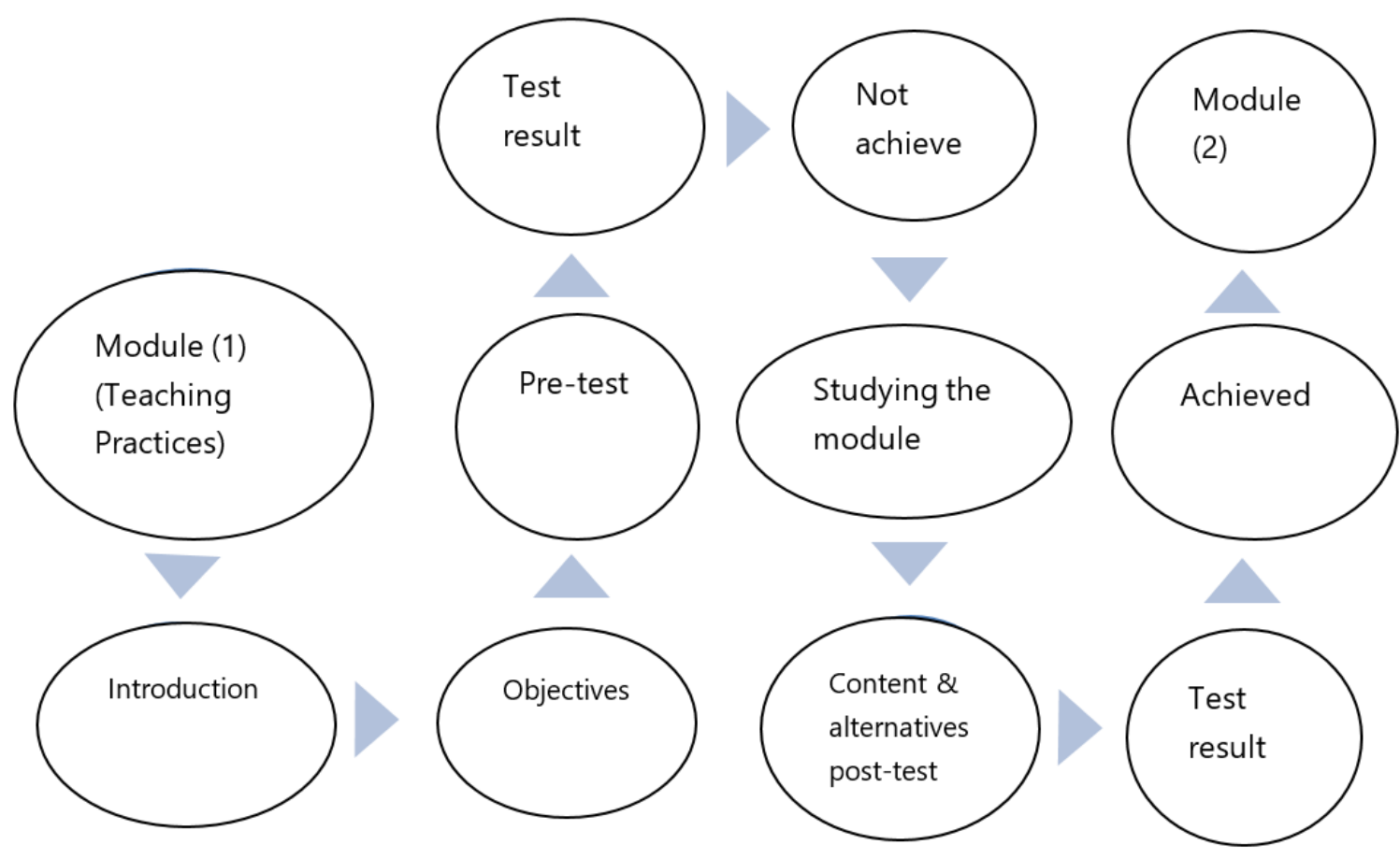

Figure 1. The business plan of the female trainee via the module

\section{Implementation of the Proposal}

The proposal is implemented through self-training. The female teacher teaches herself via (6) educational modules. Each module is related to one domain of the proposal. In addition, she can move between the first and second modules. Each module covers only one topic (procedures of teaching, technology and educational activities, interaction, skills of action research, educational materials and resources, and evaluation). The trainer follows a set of instructions and alternatives. She performs self-assessment. Hence, it is easy to move from module (1) to modules (2), (3) to (6) as they provide feedback to the training program. Time of finishing the training differs according to the female teacher's readiness and abilities. The training program can be displayed on paper, electronically, or on a CD.

\section{Evaluation of the Proposal}

It is evaluated through:

- Formative evaluation that covers the micro experimentation of the proposal on a pilot sample.

- Final evaluation (experiment of the proposal) that covers the macro experimentation of the proposal on the sample of the study.

- Achievement test that includes the evaluation of the knowledge related to the training needs in the light of the digital revolution of the female trainees.

A set of objectives are achieved by using the modules including:

1. Offering training via a new form that the effectiveness of learning was achieved via learning mastery.

2. Acquisition of self-learning skills by the trainee.

3. Changing the traditional teaching in the classroom.

4. Developing the performance of social studies female teachers.

5. The business plan of the trainee in the proposal via modules (Saleem, 2004) (see Figure 1).

\section{RECOMMENDATIONS}

- Applying and measuring the impact of the proposal provided by the present study.

- Holding courses and training programs by the end of each academic year in the light of the training needs of female teachers according to the changes of the digital age. 
- Conducting studies related to the training needs before initiating training processes.

- Interest in the aspects of time and place of training.

- Interest in the type and objective of the training courses to meet the training needs in the different fields.

- Periodically investigate the training needs of the female teachers due to the speed of updates and changes.

- Using modern information technology, e.g. distance training, in the training of the female teachers to provide the opportunity to the largest number of them.

- Interest in the digital revolution, whether in training or teaching, and adopting it as a tool of development and to improve the classroom practices of male and female teachers.

- Using the strategy of multimedia educational modules when building the training programs as it proved highly effective in a set of previous studies.

- Preparing a proposed training program to improve the teaching performance of social studies female teachers in the age of the digital revolution.

- An electronic training program to develop the skills and abilities of the female teachers in the digital age.

\section{REFERENCES}

Abu Elsamh, H., \& Rahal, S. (2012). The digital age and education. The symposium of future school. King Saud University, Riyadh.

Alahmad, K. (2005). Teacher preparation to the preparation of training. Egypt: Dar Alketab Aljamee.

Aldalan, A. A. (2004). The training needs of science teachers in the high stage in Saudi Arabia in using the educational technologies from the perspective of science teachers and supervisors (unpublished MA. thesis). College of Education, King Saud University, Riyadh.

Al-Dosari, A. (2005). The training needs of Math teachers in the high school in the field of using the computer in teaching (unpublished MA. thesis). College of Education, King Saud University, Riyadh.

Al-Ghareeb, Z. I. (2009). Information technology and education updating. Cairo: Alam Alkotob.

Al-Halafawi, W. S. (2011). E-learning: New applications. Cairo: Dar Elfekr Elaraby.

Almaghrebi, A. A. (2007). Manual of the smart management of human resources development in contemporary organizations. Cairo: Alasryia for Publishing.

Al-Otaibi, S. (2015). The training needs of the faculty in the light of effective teaching skills at the College of Science, Princess Nourah bint Abdulrahman University. International Interdisciplinary Journal of Education, 4(6).

Alsaleh, B. A. (2015). Future of technology in education over the next years and the role of family towards its. Proceedings of Family and Technology between Confrontation and Investment Symposium. College of Education, King Saud University, Saudi Arabia.

Al-Ta'ani, H. A. (2009). Training: Concepts and events (1 ${ }^{\text {st }}$ ed.). Amman: Dar El Shorouk.

Al-Zahrani, A., \& Ibrahim, Y. (2012). Science of the 21st century. Retrieved from http:/ / almarefh.net/show_content_sub.php?C\%20UV=400\&Model=M\&SubModel=138\&ID=1682\&\%20S howAll=O

Amin, M. (2010). Evaluative study on training teachers on utilizing educational technology in the light of quality standards (Unpublished Ph. D thesis). Institute of Educational Research and Studies, Cairo.

Beaudoin, M. (2004). The instructor's changing role in distance education. The American Journal of Distance Education, $4(2), 622-629$.

Berecin-Rascon, M. (2008). Perceptions of special education Paraprofassionals regarding training (Unpublished Ph.D. dissertation). University of Arizona.

Bernie, T., \& Charles, F. (2013). Skills of the 21 st century: Learning for life (Badr ibn Abdallah Elsaleh, trans.). Riyadh: King Saud University.

Clyton, T. (2006). Educational and child-psychology. New York: Houghton Mifflin Company.

Elewa, A. (2001). Identifying the training needs- Skills development series. Cairo: Etrac Publishing House.

Elshami, R. A. (2006). Encyclopedia of science and art in education and training: A theoretical curriculum and practical guide. Riyadh: Qurtubah for Publishing and Distribution.

Hassanien, A. (2014). A proposed training program based on employing the Internet for the teachers of social studies to develop their teaching competencies and skills of use. Journal of the Educational Association of Social Studies-Egypt, 133-192. 
Hussein, M. Y. (2009). The effectiveness of a proposed training program to develop the teaching skills of social studies teachers of the preparatory stage. The Scientific Journal of Faculty of Education, 1(7), 93-128.

Makrakis, V. (2005). Training teachers for new roles in the new era: Experiences from the United Arab Emirates ICT program. Proceedings of the $3^{\text {rd }}$ Pan-Hellenic Conference on Didactics of Informatics, Korinthos, Greece.

Mohammad, J. A. (2007). E-training for teachers and the requirements of application in Egypt according to the experience of some countries. Journal of Faculty of Education, Al-Azhar University, 133(2), Cairo.

Mohammed, M., \& Alharbi, H. (2016). Skills of the teacher in the era of the digital revolution and methods of development. Proceedings from Day of the Teacher, College of Education, Princess Nourah bent Abdulrahman University, October 24-26.

Munoz, C., \& Towner, T. (2012) How to use Internet in the college classroom. Paper presented at 2012 Society for Information Technology and Teacher Education Conference, Charleston, South Carolina.

National Center for Judicial Studies. (2016). Using modern methods in measuring the training needs. Proceedings from the $4^{\text {th }}$ Conference of the Managers of Judicial Centers.

Nelson, L. (2009). Creating quality special educators: An analysis of professional development of teachers of students with disabilities (Unpublished Ph.D. dissertation). University of Capella.

Newby, J., et al. (2000). Educational technology for teaching and learning (2nd ed.) New Jersey: Prentice-Hall. Inc.

Redne, W. F. (2015). Obstacles and tools of employing the technologies of e-learning in the public and private schools in Makkah (Unpublished Ph.D. dissertation). College of Education, Al-Madinah International University, Malaysia.

Saleem, S. K. (2004). Designing a training program based on educational modules to develop the competences of teachers in using multimedia labs (Unpublished MA. thesis). Faculty of Education, Ain Shams University.

Sultan, A. (2005). Technology of education and training. Kuwait: Elfalah Library.

Tawfik, A. (2006). Identifying the training needs. Cairo: Center of the Professional Experience of Administration.

Wahba, E. S. (2011). The philosophy and requirements of e-training as an introduction to substantial professional development of the teachers of the public secondary education. Journal of the Faculty of Education, Assiut University, 27(1).

\section{http://www.ejmste.com}

